\title{
A critical analysis of the hepatotoxicity cases described in the literature related to Herbalife ${ }^{\circledR}$ products
}

\author{
Flávio Ailton Duque Zambrone, Cristiana Leslie Corrêa*, Ligia Mesquita Sampaio do Amaral
}

\author{
Planitox-The Science-based Toxicology Company, Campinas, SP, Brazil
}

\begin{abstract}
The aim of this study was to assess the hepatotoxicity cases described in the literature, attributed to the consumption of Herbalife ${ }^{\circledR}$ products, and to determine whether a causal relationship exists between the reported cases of liver injury and the use of these products. A literature search was performed on the PubMed, LILACS and PAHO databases. Seven publications reporting a total of 53 cases of hepatotoxicity linked to the use of Herbalife ${ }^{\circledR}$ products were retrieved. All of the studies lacked sufficient information to some degree, whether related to patients' history, concomitant use of medication and/or other compounds (including alcohol), observations on interrupted use (dechallenge), results found with markers, viral serology and autoantibodies or observations concerning re-exposure to the products. In addition to these items, the lack of clear information on the type of products evaluated and their respective composition is an important factor to be considered. Furthermore, data quality was also questionable due to the presence of confounding factors, absence of proper exclusion of alternative explanations, and the use of questionable methods for attributing causality. Hence, an association between hepatotoxicity and consumption of these products cannot be proven based on the data collected and rigorous scientific analysis.
\end{abstract}

Uniterms: Hepatotoxicity. Herbalife ${ }^{\circledR}$. Herbalife products ${ }^{\circledR /}$ consumption/hepatotoxicity. Dietary supplements. Causality assessment.

Este estudo teve como objetivo avaliar os casos de hepatotoxicidade descritos em literatura, atribuídos ao consumo de produtos Herbalife ${ }^{\circledR}$, e verificar se é possível ou não estabelecer uma relação de causalidade entre eles. Realizou-se levantamento bibliográfico nas bases de dados PubMed, LILACS e PAHO e foram encontrados 7 manuscritos reportando 53 casos de hepatotoxicidade, relacionados ao uso de produtos Herbalife. Observou-se que todos trazem, de alguma forma, quantidade insuficiente de informações em relação ao histórico dos pacientes, ao uso concomitante de medicamentos e/ou outros compostos (incluindo álcool), às observações após a interrupção do uso (dechallenge), aos resultados referentes a marcadores e sorologia virais e autoanticorpos e às observações quanto à reexposição aos produtos. Some-se a estes fatos a falta de identificação clara e comprovada do tipo de produto envolvido, assim como sua composição. Além disso, a qualidade dos dados também é questionável devido à presença de variáveis de confundimento, ausência de exclusão adequada de explicações alternativas e ao uso de métodos discutíveis de atribuição de causalidade. Desta forma, a associação entre hepatotoxicidade e o consumo destes produtos não pode ser comprovada, após observar o conjunto dos dados coletados, utilizando-se rigor técnico-cientifico.

Unitermos: Hepatotoxicidade. Herbalife ${ }^{\circledR}$. Produtos Herbalife ${ }^{\circledR} /$ consumo/hepatotoxidade. Suplementos alimentares. Avaliação de causalidade.

\footnotetext{
*Correspondence: C. L. Corrêa. Planitox-The Science-based Toxicology Company. Av. José de Souza Campos, 1073. $8^{\circ}$ andar, conj. 801, 13025-320 Campinas - S.P., Brasil. E-mail: cris@planitox.com.br
} 


\section{INTRODUCTION}

Currently, there is a growing number of products with potential health benefits for consumers available on the food market, including foods, fortified foods (with minerals, vitamins or botanical extracts) and dietary supplements (ILSI, 2003; Schilter et al., 2003; Coppens et al., 2006; Kroes, Walker, 2004). Excessive exposure to dietary supplements and limited information available on the toxicity of some food ingredients have raised major concerns amongst scientific and regulatory communities over their safety (ILSI, 2003; Abdel-Rahman et al, 2011; Speijers et al., 2010; Van Breeman, Fong, Farnsworth, 2008; Kroes, Walker, 2004; Seef, 2009; Bunchorntavakul, Reddy, 2013; Stickel et al., 2011).

Against this background, there have been reports of adverse effects on human health related to the consumption of dietary supplements. The assessment of publications linking supplement consumption to acute and chronic liver injuries has indicated that these reports are mainly related to the consumption of products involving botanical or botanical preparations. However, the proportion of herbalinduced liver injury relative to the overall frequency of all hepatotoxicity cases is not well defined (Seef, 2009).

The aim of this article was to assess the hepatotoxicity cases described in the literature, attributed to the consumption of Herbalife ${ }^{\circledR}$ products, and to determine whether a causal relationship between the reported cases of liver injury and the use of Herbalife ${ }^{\circledR}$ products can be established or otherwise.

\section{METHODS}

A literature search was performed on the PubMed, LILACS and PAHO databases in order to identify scientific publications involving case reports of hepatotoxicity and use of Herbalife ${ }^{\circledR}$ products. The following key words were used: Herbalife, Herbalife products and Herbalife hepatotoxicity, for the period spanning from January 2000 to February 2015.

\section{RESULTS}

Thirty-two publications were found, seven of which described case reports linking hepatotoxicity to the consumption of these products. These seven publications reported 53 cases of hepatotoxicity, which are summarised below in order of publication.

Elinav et al. (2007) described twelve patients who suffered unexplained acute hepatitis during the 20022004 period in Israel. These patients had consumed various Herbalife ${ }^{\circledR}$ products prior to the onset of clinical symptoms. The twelve patients (11 women and 1 man) answered a detailed questionnaire and all medical records were collected, investigated and reviewed. Hepatocellular injury was reported in 11 cases, and mixed liver injury in 1 case (hepatocellular and cholestatic). Some patients were using other medications concomitant to the Herbalife ${ }^{\circledR}$ products and had a history of previous illness. In the causality assessment, carried out according to the World Health Organization (WHO) criteria for Causality Assessment of Suspected Adverse Reactions, 3 cases were classified as certain, 6 as probable and 3 as possible. It was noted that these entailed a list of products consumed by the patients, numbering at least 6 and up to 17 products per person. All patients stopped using the products after being diagnosed with hepatitis. Four patients were treated with corticosteroids, a further four with ursodeoxycholic acid and three (presenting with fulminant or sub-fulminant hepatic failure) with intravenous $N$-acetylcysteine. The hepatitis diagnosed was completely resolved in 11 patients. One patient with positive hepatitis B surface antigen (HBsAg+) and IgM anti-HBc antibodies (against the hepatitis B core antigen) developed fulminant liver failure, underwent urgent liver transplantation, but died due to complications resulting from the transplant. A 2-year follow up revealed no long-term complications in any of those patients who did not resume consumption of the products. Three patients that resumed consumption of Herbalife ${ }^{\circledR}$ products (based on personal decision, without informing their doctors) after normalization of liver enzymes, had a second episode of liver injury.

Although the authors stated that the analysis of these 12 patients suggested a causal association between consumption of Herbalife ${ }^{\circledR}$ products and development of acute liver injury, they also pointed out that patients with underlying liver disorders may be more susceptible to liver injury induced by the consumption of these products. Other risk factors for predisposition, which were not identified, may include genetic susceptibility, such as P450 enzyme polymorphism and individual aberrations in immune response. The authors also mentioned the fact that the exact mechanism for liver injury in their patients was not established; furthermore, the plasma-cell rich infiltrates identified in four biopsies and occasional transient presence of autoantibodies suggested the possibility of immune-mediated liver toxicity. The authors further maintained that, despite the supposed association between the consumption of Herbalife ${ }^{\circledR}$ products and the hepatic toxicity observed, it was not possible to conclude at this juncture whether the consumption of these products posed a major health threat for the general population. Toxicity 
occurred in a minority of consumers, and the authors suggest that this may have resulted from a hepatotoxic ingredient, excessive consumption of a safe ingredient or contamination during product processing, in combination with individual predisposition (Elinav et al., 2007).

Schoepfer et al. (2007) described 10 cases of hepatotoxicity potentially involving Herbalife ${ }^{\circledR}$ products in Switzerland. These cases occurred between 1998 and 2004, and were identified through a questionnaire sent to the departments of medicine of public hospitals, gastroenterology/hepatology and pathology divisions, and via the Swiss pharmacovigilance database. The population studied included 6 women and 4 men, aged between 30 and 69 years (median age of 51), with absence of comorbidity and pre-existing illness, except for one patient who presented serological evidence of past hepatitis A and $\mathrm{B}$, one who had evidence of previous hepatitis $\mathrm{E}$, and one patient who reported consumption of $50 \mathrm{~g}$ of alcohol/day. In most cases $(n=9)$, hepatocellular injury was reported, and mixed liver injury (hepatocellular/cholestatic) was observed in only one case. Causality assessment was carried out according to the World Health Organization (WHO) criteria for Causality Assessment of Suspected Adverse Reactions and revealed 2 cases as certain, 7 as probable and 1 as possible. It is worth mentioning that all of the patients consumed at least three and up to twelve different Herbalife ${ }^{\circledR}$ products at the same time, complicating the search for a specific hepatotoxin. For two of the patients, it was not known which specific products had been consumed.

According to the authors, all the patients were alive when the publication was completed, but one of these needed a liver transplant. One patient was presumed to have continued consuming Herbalife ${ }^{\circledR}$ products, but remained asymptomatic at the time of completion of the article, despite being diagnosed with cirrhosis.

The authors considered that the cases of hepatotoxicity related to the consumption of these products represented a low incidence in the context of their wide use, but did not rule out a possible cause for concern and warned about the risk of using several Herbalife ${ }^{\circledR}$ product in association. Furthermore, the authors alerted to the fact that the intake of these products is underreported by patients who believe that this type of product is not harmful to their health, rendering causality assessment even more difficult (Schoepfer et al., 2007).

Chao et al. (2008) described one case of a probable diagnosis of toxic hepatitis secondary to the consumption of Herbalife ${ }^{\circledR}$ nutritional supplements, reported in Argentina. This case involved a 63-year-old woman who presented acute cholestatic hepatitis. She reported taking three types of Herbalife ${ }^{\circledR}$ products and no medication. The result of the viral serology for hepatitis was negative. According to the causality assessment, performed using the WHO method, this case of hepatitis was classified as probable, secondary to the ingestion of Herbalife ${ }^{\circledR}$ products.

After having discontinued consumption of these products, her hepatic enzyme levels returned to normal within 21 weeks. Clinically speaking, the patient improved rapidly, with disappearance of pruritus within 4 days after discontinuing the reported food supplements.

The authors concluded that, at present, it is not possible to define the liver injury mechanism in patients who have consumed Herbalife ${ }^{\circledR}$ products. Suggestions ranged from autoimmune mechanisms to a possible obstruction in liver outflow. It has also been suggested that the presence of a previous chronic hepatic disease may increase the likelihood of potential liver injury as a result of these products. They also stressed the importance of health professionals being aware that not all of these products (plant-based food supplements) are safe, that cases of severe hepatotoxicity after their consumption have been reported, and that diagnosis and causality assessment in these cases are extremely difficult (Chao et al., 2008).

Stickel et al. (2009) described two cases of liver injury potentially related to the use of Herbalife ${ }^{\circledR}$ products reported in Switzerland. Causality was assessed according to the Council for International Organizations of Medical Sciences (CIOMS) scale criteria. Toxicological assessments, immunological sensitivity tests, microbiological contamination tests and experiments with cell cultures were carried out. No significant contamination with heavy metals, pesticides, antibiotics, alkyl phosphates or softeners were identified in the toxicological assessment of one of the products (Shake F1). No immunoallergic activation was detected on the dermal hypersensitivity tests or the lymphocyte stimulation test.

Both patients, a man (78 years old) and a woman (50 years old), presented with cholestatic hepatitis and high levels of hepatic enzymes. The man reported the consumption of alcohol as well as prescription medication while medical exams revealed an underlying disease. He reported using only one Herbalife ${ }^{\circledR}$ product (shake, two different flavours). The woman reported using seven Herbalife ${ }^{\circledR}$ products. Causality was assessed according to CIOMS assessment criteria and scored as "probable" in both cases.

The male patient stopped consuming the products and continued with routine medication, presenting an 
immediate improvement in hepatic enzyme levels and liver function, with no specific treatment. However, 8 weeks later the patient again presented high serum levels of hepatic enzymes and deteriorated hepatic functioning, with coagulopathy and hypoalbuminemia. Treatment was started with corticosteroids $(40 \mathrm{mg} /$ day) and ursodeoxycholic acid ( $15 \mathrm{mg} / \mathrm{kg} \mathrm{b}$.w.) resulting in rapid normalisation of the altered values, including the coagulation and albumin parameters. Use of the two medications was suspended three months after normalisation, and no recurrence was reported after 10 months' monitoring. In the second episode of hepatitis, a transjugular hepatic biopsy was performed and the histology showed lobular and portal/periportal hepatitis, with no eosinophilia or plasma cells, accentuated cholestasis and partial cirrhotic transformation compatible with liver injury due to toxicity. The female patient was strongly advised to discontinue all food supplements and was prescribed ursodeoxycholic acid at $15 \mathrm{mg} / \mathrm{kg}$ b.w. After 6 months without consuming these products, the clinical symptoms stabilised and normalisation of AST/ALT levels was recorded, with a sharp reduction in cholestatic bio-markers.

The authors stated that these two cases of liver injury related to the consumption of Herbalife ${ }^{\circledR}$ products added to the growing body of scientific evidence that food supplements are a rare but worrying cause of severe adverse hepatic reactions, considering that the use of plant-based supplements without the recommendation of a health professional (in some cases, concomitantly with medication) has become more prevalent amongst consumer populations. The authors also warned of the need for regulatory measures applying stricter control over food supplements, and of the need to increase awareness amongst consumers and health professionals regarding the potential for health damage caused by the use of food supplements (Stickel et al., 2009).

Chen et al. (2010) described three cases of liver injury induced by weight-loss herbal supplements reported in the United States of America, with two cases involving Herbalife ${ }^{\circledR}$ products. A standardized causality assessment was not reported. In both cases involving Herbalife ${ }^{\circledR}$ products, the patients were women, aged 37 and 53 years old, who presented with elevated liver enzyme levels and reported taking several Herbalife ${ }^{\circledR}$ products. A liver biopsy of one of the patients revealed acute necrotizing hepatitis, while the initial laboratory values of the other patient revealed a hepatocellular pattern of injury, with the liver biopsy showing cholestasis.

One of the patients received supportive treatment with fluids and nutrition. Her liver enzyme levels declined steadily from the day of admission to the eighth day of the hospital stay (day of discharge). She was monitored for several months and her symptoms continued to improve. After two months, the patient's icterus and jaundice had resolved completely. The other patient presented a history of painless jaundice and pruritus, but two months after complete abstinence from Herbalife ${ }^{\circledR}$ supplements, her jaundice resolved and liver tests normalized.

The authors concluded that it was difficult to identify the exact ingredient or mechanism which caused liver injury because both patients took several Herbalife ${ }^{\circledR}$ products. Nevertheless, they stated that the fact there has been multiple reported cases in the medical literature of hepatotoxicity associated with weight-loss herbal supplements (including Herbalife ${ }^{\circledR}$ products) cannot be overlooked, although significant liver injury induced by herbal supplements taken for weight loss purposes is a rare event. They also stressed that consideration should be given to the impact of the use of these products on patients with underlying chronic liver disease, since these products may cause worsening in their synthetic function and even fulminant liver failure. The authors therefore consider that closer monitoring of patients taking weight loss herbal supplements is needed, as is stricter regulation by government drug agencies (Chen et al., 2010).

Jóhannsson, Ormarsdóttir and Olafsson (2010) described five cases of liver injury potentially related to the consumption of Herbalife ${ }^{\circledR}$ products in Iceland during the period from 1999 to 2008. Since the original publication was published in Icelandic, we had access only to the abstract available in English, so the data could not be properly assessed. These cases involved 4 women and 1 man, aged 29 to 78 years (median age of 46); 4 patients presented with a hepatocellular and one with a cholestatic reaction. The abstract did not detail the types and number of Herbalife ${ }^{\circledR}$ products used by the patients, but it was stated that they had been used for 1 to 7 months prior to presentation. According to the causality assessment (WHO method), the cases were classified as certain $(n=1)$, probable $(n=2)$ and possible $(n=2)$ regarding their causal association to Herbalife ${ }^{\circledR}$ product consumption.

Since we did not have access to the whole publication, we do not have full information on the authors' conclusions. They stated that the hepatotoxicity observed in these cases was probably associated with the use of Herbalife ${ }^{\circledR}$ products and that hepatotoxicity due to herbal drugs and supplements is an important differential diagnosis in the investigation of liver injury (Jóhannsson, Ormarsdóttir, Olafsson, 2010).

Manso et al. (2011) described 20 cases of liver injury associated with the use of Herbalife ${ }^{\circledR}$ products in Spain. 
These cases occurred from 2003 to 2010 and were drawn from the Spanish Pharmacovigilance Centre database. The search resulted in 20 reports of liver damage, comprising 16 female and 4 male patients, aged from 36 to 63 years (mean age of 49 years) who presented high levels of bilirubin and liver enzymes (ALT, AST and AP). Of the 20 patients, 14 presented negative viral serology and 2 had positive autoantibodies. Fourteen patients were diagnosed with hepatocellular lesion, and cholestatic lesion was reported in two cases. Causality was assessed using the modified Karch and Lasagna algorithm, which ascribes levels of probability of association between drugs and adverse reactions into the following categories: definite $>$ probable $>$ possible $>$ conditional $>$ unlikely. The cases analysed were classified as follows: definite -1 ; probable -14 ; and possible -5 . In the majority of cases, several Herbalife ${ }^{\circledR}$ products were taken concomitantly, however this information was not collected for eight of the patients analysed.

The authors stated that these results support a link between the consumption of Herbalife ${ }^{\circledR}$ products and hepatotoxicity, since there was a clear temporal relation between liver injury and consumption of these products in all cases, and in most, clinical symptoms and liver parameters improved after withdrawal of Herbalife ${ }^{\circledR}$ product. The authors also pointed out that, although the component(s) responsible for the liver damage is (are) unknown, there is concern regarding adverse effects to the liver when these dietary supplements are used (Manso et al., 2011).

Besides these publications, 10 rebuttals from Herbalife ${ }^{\circledR}$ have been published to date in response to the various publications which implicate its brand (Appelhans et al., 2011; Appelhans, Frankos, Shao, 2012; Appelhans, Najeeullah, Frankos, 2013a; 2013b; 2014a; 2014b; Appelhans, Goldstein, 2011; Appelhans, Frankos, 2012; Bejar, et al., 2011; Ignarro, Heber, Henig, 2008). In summary, these rebuttals express Herbalife's objection to various methodologies which are inappropriately applied and subsequently produced inaccurate conclusions in regard to the review of cases which involve Herbalife's consumers. Herbalife has stated that the company produces hundreds of different products worldwide which also can also vary in formulation amongst the 93 markets where the products are distributed. Herbalife's main product categories include protein shakes, protein snacks, vitamins and nutritional supplements, energy and fitness drinks, and skin and hair care products. Herbalife also asserts that no single product or ingredient has been common to all the cases published to date. The company further states that it is unprecedented to publish scientific research without citing specific products or ingredients let alone being able to apply causality assessment criteria. That said, Herbalife has also acknowledged emerging research conducted by independent third party experts who have recently revisited the historical cases involving Herbalife and are also questioning the methodology by which these cases were evaluated (Teschke et al., 2013c). In many instances, these same experts are assigning weaker causality outcomes than were previously determined and certain events also appear to have been more likely associated with pre-existing etiologies amongst these consumers (e.g. viral hepatitis and alcoholism) (Teschke et al., 2013b). It can be further assumed that these potential differentials may also explain the variety of clinical presentations amongst Herbalife patients described in the literature to date.

The most recent publication found was an update on hepatotoxicity of herbal and dietary supplements (HDS). This review provided an update summary on the topic to emphasize the possibility of HDS as a potential cause of liver injury. The authors included a topic about Herbalife, summarizing all cases described in the literature and some possible explanations for them, including spoiled products, which may have been contaminated with certain germs or chemicals and could have been responsible for local series of cases of hepatotoxicity and batch-to-batch variation. They also mentioned that no further cases have been observed after the latest series from Spain in 2011(Stickel, Shouval, 2015).

\section{DISCUSSION}

After analysing these publications in which hepatotoxicity was attributed to the use of Herbalife ${ }^{\circledR}$ products, it was observed that all of them, to some degree, lacked sufficient information related to: patients' history, concomitant use of medication and/or other compounds (including alcohol), observations on discontinuation of use (dechallenge), results found with markers, viral serology and autoantibodies, observations concerning re-exposure to the products, and specifications of product use. Furthermore, data quality is also questionable due to the presence of confounding factors, absence of proper exclusion of alternative explanations, and the use of questionable methods for attributing causality.

Firstly, it should be noted that in most of the publications, the Herbalife ${ }^{\circledR}$ brand was considered as a whole, without prior analysis of the types of products involved or their composition. Secondly, in some cases the products were assessed together with plant-based products, as if all the products contained botanical 
components in their composition, which is not the case. Several products by the Herbalife ${ }^{\circledR}$ brand do not contain extracts of plants or plant parts in their composition. This important point was not mentioned by any of the authors who claimed a causal association between the Company's products and hepatotoxicity.

In this context, the attribution of causality loses merit when no specific product or chemical substance (or class of chemical substances) is indicated as causing the injury. In products containing a number of different components, including various ingredients routinely used in the food industry, as is the case for these products, this question is particularly important. Furthermore, the products cited were frequently compared to plants and/or plant-based products which were not processed industrially during manufacture. Good manufacturing practices invariably ensure the quality of the final product, plant-based or otherwise.

Another important point is that, in many cases, the combined use of various Herbalife ${ }^{\circledR}$ products was observed, in addition to synthetic and/or plant-based medications, rendering it more difficult to establish a causal agent and define a mode of action for hepatotoxicity. Excessive consumption of various products may also led to hepatic overload, potentially important in itself.

For most herbs, herb-induced liver injury (HILI) is a rare disease occurring in a few susceptible individuals, exhibiting similar characteristics to drug-induced liver injury (DILI) and other liver diseases unrelated to herbs and drugs. Furthermore, diseases affecting other organs, such as the gall bladder, bile ducts and pancreas, may mimic the symptoms of HILI and DILI. Isolated clinical presentation therefore does not suffice for diagnosing HILI, without supplementary information being provided and evaluated (Teschke et al., 2012a).

Hepatotoxicity associated with plant-based products is typically established after excluding viral, autoimmune, metabolic and anatomical causes of liver test abnormalities. Tools (scales and algorithms) are available for assessing the causality of liver injury associated with use of drugs (Fenkel, Navarro, 2011). Many publications which report cases of DILI appear to rely on clinical findings, without using any valid criteria for causality assessment (known as an ad hoc approach). Publications were identified which used the following scales for assessment: the CIOMS scale, the Naranjo scale and the WHO global introspection method (WHO method). Nevertheless, there is no systematic analysis model or scale for causality assessment in cases of HILI. Some publications take scales originally designed for medications and use them for diagnosing HILI cases. The causality assessment methods identified in publications involving herb-induced liver injury (HILI) included the ad hoc approach, the Naranjo scale, the Karch and Lasagna method, the WHO method and the CIOMS scale (Teschke, 2013a); the last 3 methods were employed in the articles that associated the use of Herbalife ${ }^{\circledR}$ products with HILI.

Patients with HILI and DILI in general have a good prognosis, but acute liver failure may occur, with a fatal outcome or the need for a liver transplant in rare cases. As there is no valid specific laboratory marker, diagnosis of DILI and HILI requires meticulous clinical assessment and the use of an appropriate diagnostic algorithm taking into consideration the specific characteristics of the hepatotoxicity.

In case series initially assumed as being DILI, alternative diagnoses are common and may have accounted for up to $47.1 \%$ of such cases in one study evaluating the accuracy of hepatic idiosyncratic adverse drug reactions initially identified in 138 patients of an English health region. In the report, primary underlying diagnoses included: bile duct stones, ischemic hepatitis, autoimmune hepatitis, sepsis, alcohol-related liver disease, Gilbert's syndrome, hepatitis from infections due to cytomegalovirus and Epstein-Barr virus, steatosis, postictal state, lymphoma, paracetamol overdose, cholangitis, thyrotoxicosis, cirrhosis due to hepatitis C and cryptogenic cirrhosis. In $15.2 \%$ of the cases, the cause was undetermined, whereas reactions were considered to be drug related in only $37.7 \%$ (Teschke et al., 2013b). The same may have occurred for cases in which hepatotoxicity was attributed to the consumption of Herbalife ${ }^{\circledR}$ products, and therefore such reports need to be analysed more carefully and judiciously.

Teschke et al. (2013b) analysed previously published cases of HILI to assess the frequency and characteristics of alternative causes, unrelated to the use of plantbased medication and dietary supplements. Among the cases assessed were several publications which linked hepatotoxicity with the consumption of Herbalife ${ }^{\circledR}$ products. Of the 42 cases of herb-induced liver injury reported in the publications evaluated, 11 cases had alternative causes (Teschke et al., 2013b). Table I shows the results expressed in number of cases initially diagnosed as HILI, number of cases with alternative causes, the causality assessment method used and the alternative causes proposed.

Thus, it can be shown that even where literature searches have identified various different plant-based products, including Herbalife ${ }^{\circledR}$ products, as responsible for causing toxic liver diseases, the data in these cases are generally confused with other alternative diagnoses. The 
TABLE I - Frequency of alternative causes proposed for cases initially diagnosed as HILI

\begin{tabular}{lcccc}
\hline Publication & $\begin{array}{c}\mathrm{N}^{\mathrm{o}} \text { of cases initially } \\
\text { diagnosed as HILI }\end{array}$ & $\begin{array}{c}\mathrm{N}^{\mathrm{o}} \text { of cases with } \\
\text { alternative causes }\end{array}$ & $\begin{array}{c}\text { Causality assessment } \\
\text { method }\end{array}$ & Alternative causes \\
\hline Elinav et al. (2007) & 12 & 4 & WHO & $\begin{array}{c}\text { Hepatitis B, primary } \\
\text { biliary cirrhosis, and } \\
\text { steatosis of the liver. }\end{array}$ \\
\hline Schoepfer et al. (2007) & 10 & 2 & WHO & $\begin{array}{c}\text { Hepatitis E and Giant } \\
\text { Cell Hepatitis. }\end{array}$ \\
\hline Manso et al. (2011) & 20 & 3 & Karch and Lasagna & $\begin{array}{c}\text { Mallory's corpuscle } \\
\text { hepatitis and liver injury } \\
\text { due to co-medication. }\end{array}$ \\
\hline
\end{tabular}

majority of these reports are flawed with respect to product quality, data presentation and the causality assessment method used (Teschke et al., 2012a).

Regarding data quality, it is important that the case report include sufficient, complete, reliable data, given the various confounding factors and absence of specific biomarkers for hepatotoxicity, which make HILI difficult to diagnose. Depending on the clinical presentation, several of these liver diseases may potentially be relevant and must be considered. This is a serious problem in retrospective analyses based on cases collected from hospitals and spontaneous reports by regulatory agencies, which are the main sources of data in publications involving cases of HILI, including the cases in which Herbalife ${ }^{\circledR}$ products are cited. Certain items are important to guarantee the validity and credibility of the data collected either from case studies or spontaneous reports, namely: competent data acquisition and complete documentation, transparent data presentation, and assessment of the temporal association of the causal relation.

With respect to the quality of the causality assessment methods, in cases where hepatotoxicity due to plants and/ or plant-based products is suspected, proper management of the causality assessment is essential to guarantee correct diagnosis and exclude alternative diseases which may require other specific treatment (TESCHKE2013a). Some items used to guarantee proper causality assessment in cases of HILI include: use of a liver-specific causality assessment method, an assessment method validated for hepatotoxicity, a structured quantitative method, assessment performed by qualified hepatologists with clinical experience, regulatory assessment with the assistance of external specialists, and a high degree of transparency in the assessment results (Teschke et al., 2012a).

As cited above, the causality assessment methods identified in publications involving herb-induced liver injury include the ad hoc approach, the Karch and Lasagna method, the Naranjo scale, the WHO method and the CIOMS scale (Teschke, 2013a), some of which were used in publications involving Herbalife ${ }^{\circledR}$ products. Teschke (2013a) hold that the most appropriate tool for causality assessment in cases of hepatotoxicity is the CIOMS scale. The CIOMS scale is specific and validated for hepatotoxicity, which is not the case for the Naranjo scale, the WHO global introspection method or the ad hoc approach. As these approaches are not specific, and not validated for causality assessment of hepatotoxicity, the authors consider them obsolete. Although documentation quality is important in cases of liver injury, it is not always possible to obtain complete information to establish causality in certain cases. Assessments based on the CIOMS method do not reject cases with incomplete data, but assess the missing items by subtracting points from the score, unlike the WHO method which does not present a list of required items, and therefore does not specifically consider data quality (Teschke et al., 2012a). Table II shows the key items for causality assessment in cases of plant-induced liver injury involved in each assessment method, demonstrating the superiority of the CIOMS scale for assessing these cases.

Another important point in cases where the suspected cause of hepatotoxicity is the ingestion of plants or plant-based products, is whether the re-exposure test (in this case unintentional) was positive, i.e. whether the patient suffered alterations in hepatic parameters and/ or recurrence of the symptoms when re-exposed to the product (without medical recommendation or controls). In the absence of accepted hepatotoxicity biomarkers for the majority of liver injuries induced by medication or plants and/or plant-based products, a positive response to re-exposure is commonly regarded as the gold standard for establishing causality in cases of hepatotoxicity, assuming that the well-established specific criteria are met (Teschke et al., 2013c).

Teschke et al. (2013c) analysed the validity of the re-exposure tests and the causality assessment methods 
TABLE II - Criteria involved in each causality assessment method (Teschke et al., 2012b)

\begin{tabular}{lcccc}
\hline Qualifying Items & CIOMS Scale & Naranjo Scale & WHO Scale & Ad hoc approach \\
\hline Application & & & & - \\
Hepatic ADRs & + & - & - & + \\
Non-hepatic ADRs & - & & & \\
Specific criteria & + & + & + & - \\
Structured & + & - & - & - \\
Quantitative & + & - & - & - \\
Liver-Specific & + & - & - \\
Hepatotoxicity-validated & & &
\end{tabular}

ADRs: adverse drug reactions.

in cases of hepatotoxicity related to the consumption of Herbalife ${ }^{\circledR}$ products with positive re-exposure tests. Of the 53 cases of suspected hepatotoxicity related to the consumption of Herbalife $\AA$ products found in the literature, they selected eight cases with a high degree of causality and positive (unintentional) re-exposure tests. In all these cases, the reports of positive re-exposure tests for hepatotoxicity caused by Herbalife ${ }^{\circledR}$ products led initially to a high degree of suspicion that the liver injury was caused by consumption of these diet supplements. However no specific criteria were applied to assess the re-exposure tests.

When the proposed criteria were used to determine whether the re-exposure tests were positive, Teschke et al. (2013c) found that not all the re-exposure tests in these eight cases could be considered positive. One was proved to be positive, another was proved to be negative, while in the other six cases, due to absent or insufficient data (ALT values), it was not possible to interpret the results (Teschke et al., 2013c). Problems with data in re-exposure tests are not exclusive to publications involving Herbalife ${ }^{\circledR}$ products. Problems of this kind have been reported in various publications relating liver injury with medication, diet supplements and plant-based products. Analysis of 30 cases over the last three decades, in which it was asserted that the re-exposure test was positive, revealed that in many cases there were no detailed descriptions of the reexposure test, and no information on the real ALT values, precluding any assessment in accordance with the criteria established for the re-exposure test to be considered positive (Teschke et al., 2013c).

Furthermore, the causality assessment methods used in the eight cases re-assessed by these authors were not specific for hepatotoxicity, and were considered obsolete for this kind of analysis. The authors re-assessed the causality in these cases using the CIOMS scale. The results are described in Table III and show much lower causality levels than those published previously (Teschke et al., 2013c).

Taking into account all the factors discussed here with respect to the particularities and limitations of causality assessment of liver injury induced by plants/ plant-based products, Teschke et al. (2012a) proposed a structured method for HILI causality assessment,

TABLE III - Comparison of initial causality assessment results with causality assessment results using the CIOMS scale (Teschke et al., 2013c)

\begin{tabular}{lccc}
\hline Patient & Publication & $\begin{array}{c}\text { Initial causality assessment } \\
\text { (method) }\end{array}$ & $\begin{array}{c}\text { Causality assessment using } \\
\text { CIOMS scale }\end{array}$ \\
\hline 1 & Hoffmann et al., 2005 apud Teschke et al., 2013c & Highly probable (--) & Probable \\
2 & Elinav et al., 2007 & Certain (WHO) & Improbable \\
3 & Elinav et al., 2007 & Certain (WHO) & Improbable \\
4 & Elinav et al., 2007 & Certain (WHO) & Excluded \\
5 & Schoepfer et al., 2007 & Certain (WHO) & Excluded \\
6 & Jóhannsson, Ormarsdóttir, Olafsson, 2010 & Probable (WHO) & Improbable \\
7 & Manso et al., 2011 & Definite (Karch and Lasagna) & Excluded \\
8 & Manso et al., 2011 & Probable (Karch and Lasagna) & \\
\hline
\end{tabular}


considering the essential information which must be present in a case report to allow assessment (Teschke et al., 2012a). The essential key elements for proper causality assessment included detailed clinical characteristics of the patients; complete description of the plant-based products and their use; details of clinical course and temporal association; values of liver parameters; alternative diagnoses; re-exposure and known hepatotoxicity of the plant.

The quantity of information which they suggest is necessary to establish an adequate causality relation demonstrates the complexity of this analysis. It also indicates the need to use specific criteria when assessing re-exposure tests and upon choosing the most complete and specific method of causality assessment, in this case for hepatotoxicity.

All this discussion refers to plant products. However, if correctly applied, it could be extended to the analysis of other types of product.

It is extremely important to consider that safety assessment of nutritional products and supplements, plant-based or otherwise, should follow general guidelines for risk assessment of chemical substances in general, in which the following stages must be judiciously evaluated: hazard identification, hazard characterization, exposure assessment and risk characterization (EC, 2003; IPCS, $1994 ; 1999 ; 2000 ; 2004 ; 2010)$. It should be noted that for these nutritional products, the history of use may provide valuable safety indications, and should be considered an essential tool in the safety assessment of these products. Thus, apart from knowledge of possible adverse events associated with chemical substances, it is important to detail the conditions of exposure to the products under assessment for a full understanding of the risks associated with consumption.

\section{CONCLUSION}

The demand for nutritional foods that can also yield health benefits has recently grown. In this group, products of plant origin have been particularly sought by the population, especially because of the historical misconception: natural is safe. In this context, is easy to tap an extensive market for natural products aimed at weight loss and popular healthy diet. Herbalife is a leading brand in this market, with a huge range of nutritional products and a substantial consumer base. Consequently, case reports involving its formulations and the possible health effects for users have been questioned.

It is important to bear in mind that the food supplements sector is regulated and supervised in most countries. Regulated products must follow Good Manufacturing Practices to ensure their homogeneity and quality, crucial points for risk evaluation and consumer safety. On the other hand, the association of adverse health effects with products from this sector has been a constant in the medical and ordinary literature. The same is true for disseminating their benefits, which often cannot be proved. Assigning an association to events is different from assigning causality. To assign causality, scientific and methodological rigor must be employed, which means that information must be complete, understandable and reliable. Moreover, the association of health risks or benefits with habits and behaviour is a daily practice, more related with risk perception than scientific proof.

In this article, the critical analysis of the publications available in the medical literature did not allow the attribution of causality between Herbalife product consumption and liver damage. Furthermore, the association between hepatotoxicity and consumption of these products cannot be proven based on data collected and rigorous scientific analysis. The technical-scientific limitation of the published papers associated with the nonexclusion of competing diagnoses and the methodological limitation of the retrospective studies greatly weakens the causality relation. In addition to these facts, the lack of clear information on the type of products evaluated and their composition is an important factor to be considered.

The majority of the authors of the publications evaluated in this review did not consistently characterize the product(s) involved. In several cases only the botanical origin of the products analysed was considered, clearly an erroneous approach. In addition, the components of the formulations, different exposed populations and the absence of effects in the majority of the consumers were not evaluated. Besides, the information collected and described in the literature does not allow speculation about the existence of sensitization in part of the population, a factor potentially involved with hepatotoxicity. The limitations of these studies and the importance of the clinical cases reported clearly demonstrate the need to include these products in health surveillance systems, with continuous nutravigilance monitoring (Schmitz, Lopez, Mackay, 2014).

Finally, in the safety assessment of food supplements and nutritional products, as important as it is to understand the potential adverse health effects (toxicity), it is critical to recognize the conditions to which the population is exposed, including the form of product presentation, its nutritional and chemical composition, purpose, proper use recommendations and target audience. Quantifying the potential exposure of the consumers to the formula 
components, through diet or otherwise, is essential for proper estimation of the health risks. The correct and rational use of the supplements and dietetic formulations can contribute to promoting health and could yield benefits for users. However, the critical and scientific evaluation of risks and benefits is necessary to guarantee the health and welfare of the population.

\section{REFERENCES}

ABDEL-RAHMAN, A.; ANYANGWE, N.; CARLACCI, L.; CASPER, S.; DANAM, R., ENONGERE, E.; ERIVES, G., FABRICANT, D.; GUDI, R.; HILMAS, C.; HINES, F.; HOWARD, P.; LEVY, D.; LIN, Y.; MOORE, R.J.; PFEILER, E.; THURMOND, T.; TURUJMAN, S.; WALKER, $N$. The safety and regulatory of natural products used as food and food ingredients. Toxicol. Sci., v.123, n.2, p.333-348, 2011.

APPELHANS K., FRANKOS V., SHAO A. Misconceptions regarding the association between Herbalife products and liver-related case reports in Spain. Pharmacoepidemiol. Drug Saf., v.21, n.3, p.333-334, 2012.

APPELHANS, K.; SMITH, C; BEJAR, E; HENIG, Y.S. Revisiting acute liver injury associated with herbalife products. World J. Hepatol., v.3, n.10, p.275-277, 2011.

APPELHANS K., GOLDSTEIN, L. Revisiting liver injury associated with dietary supplements. Liver Int., v.31, n.8, p.1239-1241, 2011.

APPELHANS K., FRANKOS V. Herbal medicine hepatotoxicity revisited. J. Hepatol. v.56, n.2, p.504-505, 2012.

APPELHANS, K.; NAJEEULLAH, R; FRANKOS, V. Letter: a correction of misinformation regarding Herbalife. World J. Hepatol., v.5, n.10, p.601-602, 2013a.

APPELHANS, K., NAJEEULLAH, R., FRANKOS, V. Letter: retrospective reviews of liver-related case reports allegedly associated with Herbalife present insufficient and inaccurate data. Aliment. Pharmacol. Ther, v.37, n.7, p.73-74, 2013 b.

APPELHANS, K., NAJEEULLAH, R., FRANKOS, V. Considerations regarding the alleged association between Herbalife products and cases of hepatotoxicity. Intern. Emerg. Med., v.9, n.5, p.599-600, 2014a.
APPELHANS, K., NAJEEULLAH, R., FRANKOS, V., SHAO, A. Outdated perspectives potentially biased conclusory statements regarding Herbalife products. J. Appl. Pharm., Sci., v.4, n.2, p.133-134, 2014b.

BEJAR E, SMITH CR, APPELHANS K, HENIG YS. Correcting a misrepresentation of hypervitaminosis A attributed to Herbalife product consumption. Exp. Mol. Pathol.; v.90, n.3, p.320-321, 2011.

BUNCHORNTAVAKUL, C.; REDDY, K.R. Review article: herbal and dietary supplement hepatotoxicity. Aliment. Pharm. Ther., v.37, n.1, p.3-17, 2013.

CHAO, S.; ANDERS, M.; TURBAY, M.; OLAIZ, E.; CORMACK, L.; MASTAI, R. Hepatitis aguda asociada al consumo de Herbalife ${ }^{\circledR}$ a propósito de un caso. Acta Gastroenterol. Latinoam., v.38, n.4, p.274-277, 2008.

CHEN, G.C.; RAMANATHAN, V.S.; LAW, D.; FUNCHAIN, P.; CHEN, G.C.; FRENCH, S.; SHLOPOV, B.; EYSSELEIN, V.; CHUNG, D.; REICHER, S.; PHAM, B.V. Acute liver injury induced by weight-loss herbal supplements. World J. Hepatol., v.2, n.11, p.410-415, 2010.

COPPENS, P.; DELMULLE, L.; GULATI, O.; RICHARDSON, D; RUTHSATZ, M.; SIEVERS, H.; SIDANI, S.; EUROPEAN BOTANICAL FORUM. Use of botanicals in food supplements. Ann. Nutr. Metab., v.50, p.538-554, 2006.

ELINAV, E.; PINSKER, G.; SAFADI, R.; PAPPO, O.; BROMBERG, M.; ANIS, E.; KEINAN-BOKER, L.; BROIDE, E.; ACKERMAN, Z.,KALUSKU, D.; LEV, B.; SHOUVAL, D. Association between consumption of Herbalife ${ }^{\circledR}$ nutritional supplements and acute hepatotoxicity. J. Hepatol., v.47, n.4, p.514-520, 2007.

EUROPEAN COMMISSION. EC. Technical guidance document on risk assessment: Part I. European Communities: [S.n.], 2003.

FENKEL, J.M.; NAVARRO, V.J. Review: herbal and dietary supplement-induced liver injury. Gastroenterol. Hepatol., v.7, n.10, p.695-696, 2011.

IGNARRO, L., HEBER, D., HENIG, Y.S. Herbalife nutritional products and liver injury revisited. J. Hepatol., v.49, n.2, p.291-293, 2008. 
INTERNATIONAL LIFE SCIENCES INSTITUTE. ILSI. Guidance for the safety assessment of botanicals and botanicals preparations for use in food and food supplements. Brussels,: ILSI Europe, 2003. 47 p.

INTERNATIONAL PROGRAMME ON CHEMICAL SAFETY. IPCS. Environmental health criteria 170: assessing human health risks of chemicals: derivation of guidance values for health-based exposure limits. Geneva, Switzerland: World Health Organization, 1994. Available at: <http://www.inchem.org/documents/ehc/ehc/ehc170. $\mathrm{htm}>$. Accessed on: 11 Sep. 2014.

INTERNATIONAL PROGRAMME ON CHEMICAL SAFETY. IPCS. Environmental health criteria 210: principles for the assessment of risks to human health from exposure to chemicals. Geneva, Switzerland: World Health Organization, 1999. Available at: $<$ http://www.inchem.org/ documents/ehc/ehc/ehc210.htm>. Accessed on: 11 Sep. 2014.

INTERNATIONAL PROGRAMME ON CHEMICAL SAFETY. IPCS. IPCS risk assessment terminology. Geneva, Switzerland: World Health Organization, 2004. Harmonization Project Document no.1. Available at: $<$ http://www.inchem.org/documents/harmproj/harmproj/ harmproj1.pdf $>$. Accessed on: 11 Sep. 2014.

INTERNATIONAL PROGRAMME ON CHEMICAL SAFETY. IPCS. Training module no.4: general scientific principles of chemical safety. Geneva, Switzerland: World Health Organization, 2000. Available at: $<$ http:// whqlibdoc.who.int/hq/2000/WHO_PCS_00.8_pp1-104. pdf $>$. Accessed on: 11 Sep. 2014.

\section{INTERNATIONAL PROGRAMME ON CHEMICAL} SAFETY. IPCS . WHO human health risk assessment toolkit: chemical hazards. Geneva, Switzerland: World Health Organization, 2010. (Harmonization Project Document n.8). Available at: <http://www.inchem.org/ pages/harmproj.html>. Accessed on: 11 Sep. 2014.

JÓHANNSSON, M.; ORMARSDÓTTIR, S; OLAFSSON, S. Hepatotoxicity associated with the use of Herbalife. Laeknabladid, v.96, n.3, p.167-172, 2010. [Abstract].

KROES, R.; WALKER. R. Safety issues of botanicals and botanical preparations in functional foods. Toxicology, v.198, n.1-3, p.213-220, 2004.
MANSO, G.; LOPEZ-RIVAS, L.; SALGUEIRO, M; DUQUE J.; JIMENO, F.; ANDRADE R., LUCENA, M. Continuous reporting of new cases in Spain supports the relationship between Herbalife ${ }^{\circledR}$ products and liver injury. Pharmacoepidemiol. Dr. S., v.20, n.10, p.1080-1087, 2011.

SCHOEPFER, A.M.; ELGEL, A.; FATTINGER, K.; MARBET, U.; CRIBLEZ, D.; REICHEN, J.; ZIMMERMANN, A.; ONETA, C. Herbal does not mean innocuous: Ten cases of severe hepatotoxicity associated with dietary supplements from Herbalife ${ }^{\circledR}$ products. J. Hepatol., v.47, n.4, p.521526, 2007.

SEEF, L.B. Are herbals as safe as their advocates believe? $J$. Hepatol., v.50, n.1, p.13-16, 2009.

SCHILTER, B.; ANDERSSON, C.; ANTON, R.; CONSTABLE, A.; KLEINER, J.; O'BRIEN, J.; RENWICK A.; KORVER, O.; SMIT; F.; WALKER, R. Guidance for the safety assessment of botanicals and botanicals preparations for use in food and food suplements. Food Chem. Toxicol., v.41, n.12, p.1625-1649, 2003.

SCHMITZ, S.; LOPEZ, H.; MACKAY, D. Nutravigilance: principles and practices to enhance adverse event reporting in the dietary supplement and natural products industry. Int. J. Food Sci. Nutr., v.65, n.2, p.129-34, 2014.

SPEIJERS, G., BOTTEX, B.; DUSEMUND, B.; LUGASI, A.; TÓTH, J.; AMBERG-MULLER, J.; GALLI, C.; SILANO, V.; RIETJENS, I. Safety assessment of botanicals and botanical preparations used as ingredients in food supplements: testing an european food safety authority tiered approach. Mol. Nutr. Food Res., v.54, n.2, p.175185, 2010.

STICKEL, F.; KESSEBOHM, K.; WEIMANN, R.; SEITZ, H.K. Review of liver injury associated with dietary supplements. Liver Int., v.31, n.5, p.595-605, 2011.

STICKEL, F.; DROZ, S.; PATSENKER, E.; BOGLISTUBER, K.; AEBI, B.; LEIB., S. Severe hepatotoxicity following ingestion of Herbalife $\AA$ nutritional supplements contaminated with Bacillus subtilis. J. Hepatol., v.50, n.1, p.111-117, 2009.

STICKEL, F.; SHOUVAL, D. Hepatotoxicity of herbal and dietary supplements: an update. Arch. Toxicol., v.89, n.6, p.851-865, 2015. 
TESCHKE, R.; FRENZEL, C.; GLASS, X.; SCHULZE, J.; EICKHOFF, A. Herbal hepatotoxicity: a critical review. $B r$. J. Clin. Pharmacol., v.75, n.3, p.630-636, 2012 a.

TESCHKE, R.; WOLFF, A.; FRENZEL, C.; SCHULZE, J. EICKHOFF, A. Herbal hepatotoxicity: a tabular compilation of reported cases. Liver Int., v.32, n.10, p.1543-1556, 2012 b.

TESCHKE, R.; Herbal hepatotoxicity and WHO global introspection method. Ann. Hepatol., v.12, n.1, p.11-21, 2013a.

TESCHKE, R.; SCHULZE, J.; SCHWARZENBOECK, A.; EICKHOFF, A.; FRENZEL, C. Herbal hepatotoxicity: suspected cases assessed for alternative causes. Eur. J. Gastroen. Hepatol., v.25, n.9, p.1093-1098, 2013 b.
TESCHKE, R.; FRENZEL, C.; SCHULZE, J .; SCHWARZENBOECK, A.; EICKHOFF, A. Herbalife hepatotoxicity: Evaluation of cases with positive reexposure tests. World J. Hepatol., v.5, n.7, p.353-363, 2013 c.

VAN BREEMAN, R.B.; FONG, H.H.S.; FARNSWORTH, N.R. Ensuring the safety of botanical dietary supplements. Am. J. Clin. Nutr, v.87, Suppl., p.509S-513S, 2008.

Received for publication on $22^{\text {th }}$ January 2015 Accepted for publication on $26^{\text {th }}$ August 2015 